\title{
Helle Dam*
}

\section{En analyse af referenceforhold $i$ bestemte nominalsyntagmer i spansk}

\section{Indledning}

Afhandlingen, hvis originaltitel er a referential analysis of definite NPs in Spanish, beskæftiger sig grundlæggende med grammatiske konstruktioners betydning. Jeg har specifikt valgt at analysere den grammatiske konstruktion der betegnes som nominalsyntagme (NP), dvs. substantivgruppe, i spansk.

NPet er bl.a. karakteriseret ved at kunne indledes af forskellige determinativtyper og ved at kunne være mere eller mindre komplekse, dvs. at de kan udvides med attributiv. Den størrelse som analyseres i afhandlingen, er et simpelt NP, dvs. et NP bestående af et determinativ og et substantiv, hvor determinativet er enten den bestemte artikel, el/la, eller den ubestemte artikel, un/una. Hovedvægten ligger på bestemte NPer, og analysen af ubestemte syntagmer kan betragtes som perspektiverende.

Opbygningen af det spanske NP, dvs. de dele det består af og sammenhængen mellem disse dele, ekspliciteres i X-bar Teoriens træstruktur. NPs interne struktur kan generelt betegnes som hierarkisk. Formålet med en hvilken som helst notationsform må være at eksplicitere relevante aspekter af en struktur. Fordelen ved X-bar Teorien som notationsredskab er at den netop ekspliciterer hierarkisk struktur. Inden for rammerne af denne teori defineres NP som et determinativsyntagme (DP) hvor determinativet således er kerne og NP et komplement.

Selvom DP altså er den teoretisk passende term, bruger jeg i afhandlingen termen NP, der i litteraturen er standardbetegnelsen for syntagmet.

\footnotetext{
* Helle Dam

Spansk Institut

Handelshøjskolen i Arhus

Fuglesangs Allé 4

DK-8210 Arhus V
} 
Bestemte og ubestemte NPer analyseres på samme måde syntaktisk, men i den semantiske analyse er de forskellige. Det er afhandlingens primære formål at give en analyse af referenceforhold i simple bestemte NPer, og sekundært af ubestemte NPer med udgangspunkt i principperne om generalisering og ensartethed.

\section{Reference: forholdet mellem sprog og verden}

Det kan på ingen måde betragtes som noget nyt at problematisere forholdet mellem sprog og verden, dvs. det forhold som kaldes reference. Når det alligevel er genstand for undersøgelse både i lingvistikken og i filosofien, skyldes det at det er et fænomen der på flere måder er problematisk at håndtere.

Den klassiske opfattelse af reference betragter forholdet mellem sprog og verden som en ligefrem relation hvor sproglige udtryk refererer direkte til ting ude i verden. Ifølge denne tankegang redegør man for sproglige udtryks betydning og reference ved at specificere de betingelser der skal opfyldes i verden for at et sprogligt udtryk er sandt.

Det er et fundamentalt problem ved denne opfattelse at langt fra alle sproglige størrelser har modstykker i den virkelige verden. Det drejer sig f.eks. om leksemer som [HEKS], [TROLD] og [FE]. Det må være et krav til en referenceteori at den tager højde for sådanne sproglige forekomster. En teori der håndterer det problem på en enkel måde, er teorien om mentale rum (the theory of mental spaces) der er udviklet af Gilles Fauconnier. Ifølge denne teori er forholdet mellem sprog og verden ikke ligefremt. Sproget repræsenterer derfor ikke genstande i verden direkte. Et sprogligt udtryk udløser derimod en konceptualisering af sådanne genstande. Reference foregår i den forstand mellem genstande i en kognitiv model, det som kaldes et mentalt rum i Fauconniers teori, snarere end direkte mellem sproglige udtryk og ting i verden.

\section{Reference: den taksonomiske tilgang}

Når man i lingvistikken taler om reference, interesserer man sig typisk for hvordan man taler om genstande. Reference bruges nemlig oftest om sproglige udtryk der beskriver genstande, det vil altså sige NP og ikke f.eks. VP. 
Man forsøger i lingvistikken at afdække hvordan forskellige NPer kan pege på eller beskrive genstande i verden på forskellige måder. Udgangspunktet for sådanne undersøgelser er de forskellige determinativtyper som NP kan indledes af. Det udtrykker man typisk i en klassifikation over forskellige reference- eller anvendelsestyper. Det betegnes $i$ afhandlingen som den taksonomiske tilgang til reference.

Tilgangen eksemplificeres ved tre studier af henholdsvis John Hawkins, Iørn Korzen og Michael Herslund et al. Hver af disse opstiller forskellige klassifikationer på baggrund af forskellige parametre.

Generelt betragtet kan den taksonomiske tilgang problematiseres på forskellig måde. For det første er det ikke alle NPer der lader sig klassificere entydigt $i$ en taksonomi. For det andet kan sådanne taksonomiske fremstillinger ved konfrontation med data generere nye typer som der ikke er taget højde for i systemet. Man vil i yderste konsekvens fortsætte med at danne nye typer og dermed skabe et meget detaljeret og derved uoverskueligt system. Hvis referencetyper fremstilles som præeksisterende, statiske kategorier, er det ikke muligt at producere en homogen fremstilling af den bestemte artikel, og af artikelparadigmet i det hele taget, som udtryksklasse.

Hertil kommer at mange grammatikere i forbindelse med den bestemte artikel taler om en decideret artsartikel. En logisk konsekvens heraf er at der så også må være en partikulær artikel, dvs. flere forskellige bestemte artikler.

I overensstemmelse med hovedtesen om at en given teori bør gøre det muligt at opstille generaliseringer over et givet studieobjekt og på den måde muliggøre en ensartet analyse, vil jeg foreslå en tilgang hvor reference, snarere end at være en præeksisterende relationstype, er en relation der etableres mentalt hos modtagere af sproglige udtryk i en given ytringssituation. Reference er dermed defineret som et forhold der skabes $i$ en fortolkningsproces. Referencetyper er i den forstand ikke fastlagt på forhånd, men fremkommer som resultat af en fortolkningsproces.

Det er den betydning der er indeholdt i de sproglige udtryk der er input til fortolkningen. Den sproglige betydning er altså den basale information som modtager anvender til etablering af reference.

For at modtager kan konstruere betydning, må sproglige udtryk nødvendigvis indeholde information. Den information som sproglige udtryk har, mener jeg består i en slags basal betydning som kan kaldes "kon- 
ventionel betydning", dvs. en betydning som sprogbrugere i et samfund har vedtaget $i$ kraft af brugen af sproget. Det er i den forstand at sproglige udtryk er informationsbærende.

Den information som sproglige udtryk giver til modtagers fortolkningsproces, er kompleks. Betydningsbegrebet defineres som et kompleks af grammatisk og leksikalsk betydning. Grammatisk og leksikalsk betydning er kategorialt forskellige i den forstand at leksikalsk betydning er beskrivende, og grammatisk betydning er instruktionel, dvs. den indeholder en instruks til modtager om at forstå noget på en bestemt måde. Den bestemte artikel er altså, som grammatisk størrelse, instruktionel. Kort sagt kan man sige at den instruerer modtager om at forstå den kategori som den leksikalske kerne beskriver på en bestemt måde.

Grammatisk betydning er karakteriseret ved at kun én betydning danner udgangspunkt for fortolkningsprocessen, dvs. den er entydig. I overensstemmelse hermed opstiller jeg en enhedsbetydning, eller enhedsværdi, bl.a. for den bestemte og den ubestemte artikel.

Det er altså information fra de sproglige udtryk, her den bestemte artikel efterfulgt af et substantiv, der er basis for den fortolkningsproces der fører til etablering af reference. Modtager trækker dog også på andre informationskilder for at nå frem til en præcis fortolkning, nemlig den sproglige kontekst, den situationelle kontekst og baggrundsviden.

I afhandlingen bruger jeg Fauconniers notationsapparat, mental spaces, til at vise modtagers fortolkningsproces.

\section{Teorien om mentale rum}

I korte træk kan teorien om mentale rum betegnes som en kognitiv teori der repræsenterer de mentale processer som aktiveres i fortolkningen af sproglige udtryk. Teorien forklarer hvad det vil sige at forstå et sprogligt udtryk, snarere end hvad det vil sige at have forstået det. I løbet af en diskurs skabes en række mentale modeller, mentale rum hos Fauconnier, der forbindes og struktureres på basis af information fra både sproglige udtryk, kontekst og baggrundsviden. Man kan sige at modellen for en sætning opdateres fortløbende ved fortolkning af de efterfølgende sproglige udtryk.

I fortolkningen af en diskurs skabes der altså en række mentale rum. Man kan sige at disse rum modellerer modtagers fortolkning af de situ- 
ationer som en diskurs beskriver. Rummene kan f.eks. være struktureret temporalt sådan at forskellige rum modellerer forskellige tidsrum beskrevet i diskursen.

I de mentale rum indsættes der genstande, eller elementer som de kaldes, af bl.a. NPer. Elementer i forskellige rum forbindes ved det som Fauconnier kalder pragmatiske konnektorer. Det vil sige de mentale forbindelser som modtager skaber mellem elementer i sin fortolkningsproces.

\section{Analyse af bestemte nominalsyntagmer}

Inden for rammerne af denne teori opstiller Fauconnier en overordnet karakteristik af henholdsvis den bestemte og den ubestemte artikel. Princippet for den bestemte artikel er som følger:

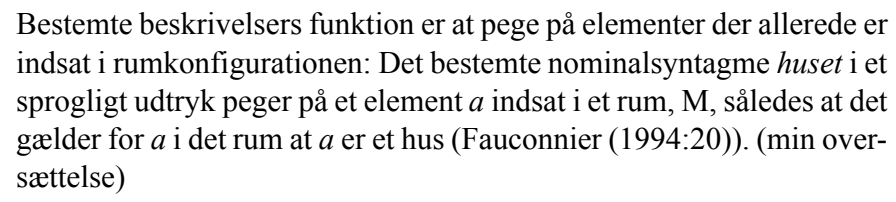
indsat i rumkonfigurationen: Det bestemte nominalsyntagme huset $\mathrm{i}$ et sprogligt udtryk peger på et element $a$ indsat i et rum, M, således at det gælder for $a$ i det rum at $a$ er et hus (Fauconnier (1994:20)). (min oversættelse)

På baggrund af Fauconniers princip formulerer jeg, i overensstemmelse med den antagelse at grammatisk betydning er instruktionel, følgende instruktionelle værdi for den bestemte artikel:

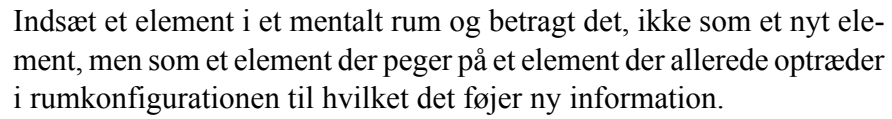

Modtager instrueres således om at identificere et element der allerede er tilstede i rumkonstruktionen. Med andre ord, den bestemte artikel rummer en forudsætning, man kan sige at den implicerer præsupposition. Denne instruktionelle værdi danner udgangspunkt for fortolkningen af alle forekomster af bestemte NPer. Dvs. at ligegyldigt hvilken kontekst det bestemte NP indgår i, vil instruksen altid være den samme. Princippet kan illustreres ved følgende eksempel:

1. El niño está durmiendo ("barnet ligger og sover")

Den bestemte artikel, $e l$, instruerer modtager om at indsætte et element, $x$, i et rum, som vi kan kalde M. $x$ i M svarer til beskrivelsen i substantivet [NIÑO]. Dette ses i den nedenstående figur: 


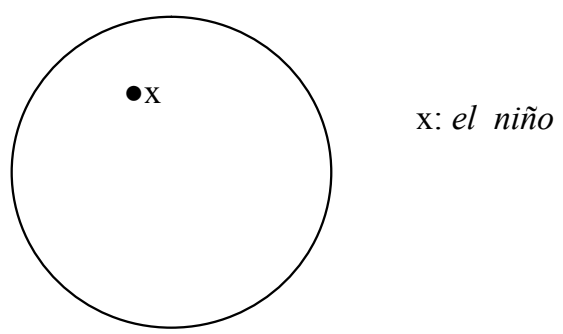

$\mathrm{M}$

Ifølge den instruktionelle værdi for den bestemte artikel skal $x$ identificere et element der allerede er indsat i rumkonstruktionen. Med andre ord kan vi sige at eksistensen af et andet element, $x$ ', forudsættes i et andet rum der allerede er skabt. Dette rum betegner jeg som et præsuppositionsrum. $x$ i M er altså forbundet til et element i et andet rum, præsuppositionsrummet, som det ses her:

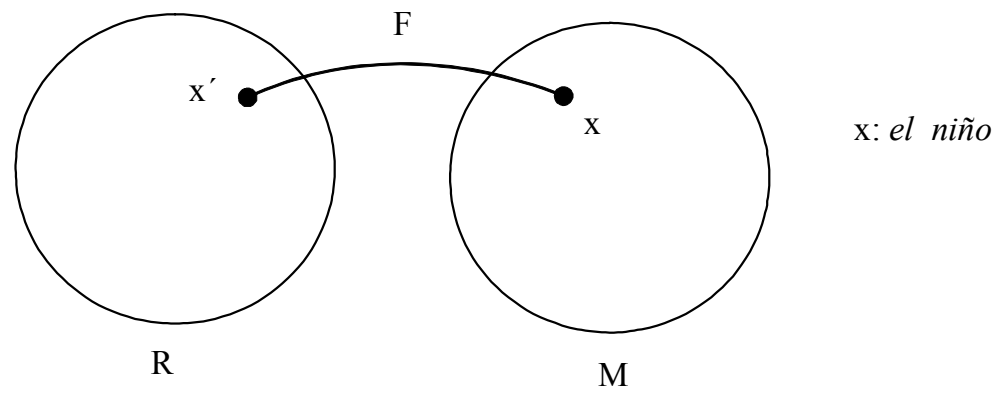

Relationen mellem to elementer i to forskellige rum, som eksemplificeret i denne figur, betegner jeg som en referencerelation. Et bestemt NP vil altså altid instruere modtager om at indsætte et element $\mathrm{i}$ et mentalt rum som relaterer sig til et andet element der allerede er indsat i rumkonstruktionen således at der skabes en referencerelation.

Det element som et element der indsættes af et bestemt NP identificerer, kan indsættes på forskellig vis. For eksempel ved et ubestemt NP der optræder tidligere i teksten, eller ved henvisning til situationen. Det er 
netop det at det bestemte NP kan foranledige identifikation af genstande, eller elementer, på forskellige måder der giver anledning til at nogle opstiller klassifikationer over forskellige anvendelses- eller referencetyper. Som jeg lige har nævnt, mener jeg at den bestemte artikel har en enhedsværdi der er udgangspunktet for en fortolkningsproces. Det materiale der anvendes til denne proces er uvedkommende for analysen af den bestemte artikel. Og det der ellers betegnes som forskellige referencetyper, mener jeg er forskellige informationskilder som modtager benytter i sin fortolkning.

Denne fortolkning kan så "påvirkes" på forskellig måde, afhængig af information dels fra anden grammatisk betydning indeholdt i NP, dels fra den sproglige kontekst og den situationelle kontekst, dels fra baggrundsviden.

Generelt set kan man sige at vi er i stand til at forstå elementer i rum på to grundlæggende forskellige måder. Det næste eksempel vil, afhængig af konteksten, kunne fortolkes på to måder:

2. El teatro es fundamental ("teatret er fundamentalt")

Det element som el teatro indsætter i et rum, kan forstås enten på den måde at teatret som institution er vigtigt, f.eks. for samfundet i det hele taget, eller således at et bestemt teater er vigtigt f.eks. for en bestemt by. Eller med andre ord, det kan enten forstås som en samling af de egenskaber der essentielle for at være et teater, dvs. som en rolle, eller således at disse egenskaber samles i et individualiseret teater, dvs. rollen tillægges en værdi. Konsekvensen heraf er at elementer primært er roller som så sekundært kan udfyldes af en værdi. Rolle- og værdibegreberne er en generalisering der dækker over f.eks. generisk og partikulær reference.

Hvis rolle-/værdidistinktionen skal forklares på en ensartet måde i rumkonstruktionen, må det forholde sig sådan at NP altid indsætter både en rolle og en værdi $i$ et rum.

Afhandlingen sandsynliggør gennem analyser af spanske NPer i forskellige konteksttyper den antagelse af reference er resultatet af en fortolkningsproces foretaget af modtager af sproglige udtryk. Denne proces ekspliciteres i mentale rumkonstruktioner. 


\section{Opsummering}

Afhandlingen bygger altså på den antagelse at reference er resultatet af en fortolkningsproces foretaget af modtagere af sproglige udtryk. Reference er en mental relation mellem genstande. Inden for rammerne af teorien om mentale rum er reference en relation mellem elementer $i$ mentale rum.

Forskellige NP typer har en singulær instruktionel værdi i kraft af det determinativ som de indledes af. Den bestemte artikels værdi er karakteriseret som en instruks til modtager om at indsætte et element $i$ et mentalt rum og forbinde det med et element der allerede er indsat i modellen. Elementet der således indsættes i modellen, kan opfattes enten som en rolle eller som en værdi.

Analysen af forekomster af bestemte NPer i forskellige kontekster sandsynliggør en ensartet og generel grammatisk og semantisk analyse af den bestemte artikel.

\section{Litteraturhenvisninger}

Allwood, J.S., Andersson, L. \& Dahl, Ö. 1972: Logikför lingvister. Lund: Studentlitteratur.

Bosque, I. 1999: El nombre común. In Bosque, I. \& Demonte, V. (eds.). Gramática Descriptiva de la Lengua Española, vol. 1. Madrid: Editorial Espasa Calpe. 3-75.

Cann, R. 1993: Formal Semantics. Cambridge: Cambridge University Press.

Dam, H. 2001: A Referential Analysis of Definite NPs in Spanish. Ph.d.-afhandling. Århus: Handelshøjskolen i Århus.

Fauconnier, G. 1994: Mental spaces. Cambridge: Cambridge University Press.

Haegeman, L. 1994: Government and Binding Theory. Oxford: Blackwell.

Hawkins, J. A. 1978: Definiteness and Indefiniteness. London: Croom Helm.

Herslund, M. (ed.) 1999: Nominalsyntagmet. In DET FRANSKE SPROG, foreløbig version, kap. VI. København.

Korzen, I. 1998: At tale om ting. In København: Copenhagen Working Papers in LSP, vol. 2.

Lyons, J. 1977: Semantics. Vol. I-II. Cambridge: Cambridge University Press.

Thrane, T. 1997: Understanding Semantics. In Bache, C. and Klinge, A. Sounds, Structures and Senses. Odense: Odense Universitetsforlag. 